\title{
The final edition of Economic \& Labour Market Review
}

Welcome to the last ever edition of ELMR. Since 2007 this has been the Office for National Statistics' flagship journal, each month providing the latest commentary, analysis, research and statistics on the UK economy and labour market. The decision to discontinue ELMR has been taken alongside ONS's plans to launch its new website at the end of August 2011. This will offer a new and improved way for ONS to deliver statistics and articles online.

Most of the suite of economics and labour market tables on the ELMR website will no longer be updated, but in each spreadsheet a note has been attached to say when the table was last updated and where the information can now be found. The only ELMR tables that will continue to be published each month are the Further labour market tables as these are not published elsewhere. Dates for these releases are on the National Statistics Publication Hub. Once the new website goes live these will become supplementary tables to the Labour Market statistical bulletin.

The monthly Economic Review article which provides the latest perspective on the UK economy from the point of view of ONS's statistics has also been discontinued. However, ONS remains committed to publishing relevant commentary on all its key economic statistics and intends to publish a note alongside each month's National Accounts release. The quarterly Regional Economic Indicators will continue to be published as usual and a link to this can be found from the Regional Trends part of the ONS website.

The ELMR mail box will also closedown towards the end of May 2011, and any requests for information or data after then should be made to ONS's customer contact centre on 08456013034 or at info@statistics.gov.uk.

\section{Further information}

ONS's announcement regarding the postponement of the new website's launch and other details about the ONS's Web Development Project can be found at:

www.ons.gov.uk/about/what-we-do/programmes-projects/web-development/index.html

\section{Contact}

web.development.programme@ons.gov.uk

elmr@ons.gov.uk 